\title{
Article \\ Sustainable Land Planning in Case of Decentralized Land Authorities
}

\author{
Xieer Dai * (D) \\ * Department of Geography, The Hebrew University of Jerusalem; daixieer@gmail.com
}

\begin{abstract}
The main focus of this paper is to analyze the effect of local public finance on spatial land use through economic models and empirical evidence from Israel. The theoretic models extends the Alonso-Mill-Muth model by incorporating local public finance. The first finding is that steady population growth provides a channel for land capitalization through the mechanism of long term land property right. This implies a possible conflict of interest if ownership of land leasing revenue and the ad valorem property tax are not consistent. The empirical section examines one of the implications derived from the models highlighting a possible inconsistency between central and local governments due to land ownership centralization. This causes local tax revenue inequality among Israeli municipalities. Statistical evidence shows that cities with a larger share business land use can generate more tax without assistance from the central government, and are therefore more fiscal independent. Fiscal status has a significant effect on the planning time of residential construction. Municipalities with higher local tax revenues have shorter planning time(higher probability of acceptance) conditional on the plan's size and other features.
\end{abstract}

Keywords: planning delay; land depletion; local fiscal policy

Citation: Lastname, F.; Lastname, F.; Lastname, F. Title. Preprints 2021, 1, 0. https://doi.org/

Received:

Accepted:

Published:

Publisher's Note: MDPI stays neutral with regard to jurisdictional claims in published maps and institutional affiliations.

\section{Introduction}

Urban expansion and population growth raise perennial dilemmas for urban planners. On the one hand, they are faced with the question of how to efficiently allocate limited land for different land uses, on the other hand sustaining steady urban population growth. This question is particularly relevant in countries where land is held or owned publicly and this has received less attention from researchers. In these countries the ownership of land usually means leasing rights for a certain period of years. In China, for example, land grants or leases run from 40-70 years according to different land purposes and in Israel for 49 or 98 years. This paper studies a dynamic scheme of land planning during urban growth when there is a conflict between local and central land authorities. Systematic reasons for land planning delay from Israel suggest that we need to pay special attention to the role of regulation and planning in perpetuating the city expansion needed to ensure urban dominance.

To analyze this scheme, I formulate a local public good model based on the AlonsoMuth-Mill model with a few extensions. First, the types of land used for working include both commercial and residential. The second crucial assumption is that housing is durable: the reallocation of a parcel of land for another type of use has fixed cost. Last, I introduce competitive local authorities which provide public amenities by levying the property tax on buildings for different land use. In addition, I analyze the dynamics of urban expansion under the framework of [1] to let the city be completely rebuilt from scratch to fit the new conditions. This is often seen as a reasonable simplification because the comparative statics fit well with comparisons of actual cities built under different conditions such as growing city with population increasing steadily.

I apply the theoretical model above to analyze the effect of planning centralization on housing supply in Israel. As Israel is a perfect example for monocentric urban structure with Tel Aviv the dominant metropolitan area where the economic values are higher than other locations. [2] demonstrates the house prices, land prices, and structural density of the localities in Israel as the gradients on traveling time from Tel Aviv in all directions. [3] 
show house prices in Israeli localities on a north-south axis along the Mediterranean are decaying from the Tel Aviv as the unique center ${ }^{1}$.

Since building is durable, not only is development irreversible in the short run, but also the reallocation of land use has friction. As a result, such conflict may arouse inefficient market outcome such as urban sprawl and the insufficient supply of housing. Thus, even in the countries where land is privately owned land use is not solely the outcome of the market forces. Urban planners have an arsenal of regulatory tools at their disposal to achieve desirable land planning through zoning, property tax and other regulations. For example, [4] show that an urban planner can implement optimal land use by controlling parcel size (the intensity of development). Property transactions usually play an important role to determine whether a parcel of land is developed, how it is developed and who ends up using it. In reality, land as an input for production and space for dwelling has shaped the urban area into residential and commercial parcels within a city which follows more complicated patterns in case of mixed ownership.

Another remarkable feature in these countries is high housing prices which are usually directly caused by a land supply constraint. There are at least two reasons why residential land is not sufficiently supplied. First, in a growing or declining city, the supply of residential land could be under or over the socially desirable amount due to the inconsistent expectations between developers and planners under the assumption that development is irreversible [5] . Another reason stems from misallocation. Land prices for commercial and industrial use are usually higher than residential prices other business tax income notwithstanding. Local government lacks the incentive to allocate residential land. The misallocation problem becomes especially severe in the case of an agglomeration economy when the location choices of firms have externality effect for new firm entries.

The paper is organized as follows, chapter 2 discusses the background. Chapter 3 formulate the theoretical models. Chapter 4 studies the empirical evidence. Chapter 5 concludes.

\section{Background}

\subsection{The House Prices Crisis in Israel}

Israel has experienced rapidly increasing cost of living that reached a peak in 2011 and lead to a social crisis. It is well documented that rising house prices have been driven by by both persistently high demand for dwelling and supply limitations due to slow and inefficient regulatory procedures [6] . Most land policies in Israel focus on state-owned land, since the vast majority of land in Israel is publicly owned (93.6\%). Even though the privately-owned land share is low, it has a crucial position in urban planning, since private land is mainly located in larger urban municipalities founded before 1948. For both ideological and regulatory reasons, a dedicated regulatory land authority (the ILA) was established in 1960 to administer this resource. According to ILA the government owns around $69.4 \% 1$ the Jewish National Fund around $11.7 \%$ and the government Development Authority another $12.5 \%$. The national financial environment such as low interest rates and the absence of alternative investment horizons have exacerbated the situation.

The planning system in Israel is based on the Planning and Building Law of 1965 which defines planning institutions and authorities, the types of plans and the hierarchy between them. It is centralized and provides strong oversight over local planning decisions. The national government plays a key role in land-use planning providing most representatives for the planning institutions at the national level (the National Planning and Building Committee) and the regional level (District Planning Committees). It therefore not only has the power to guide development through the creation of binding national and district master plans but is also responsible for the approval of many plans at the local level. [6] found ILA tenders have a small impact on new construction (also only about a half of new

1 The only other case in which prices rise as one approaches the city is Jerusalem and even there the price of a square meter of housing is about 25 percent lower than in Tel Aviv. 
reserve ratio.jpg

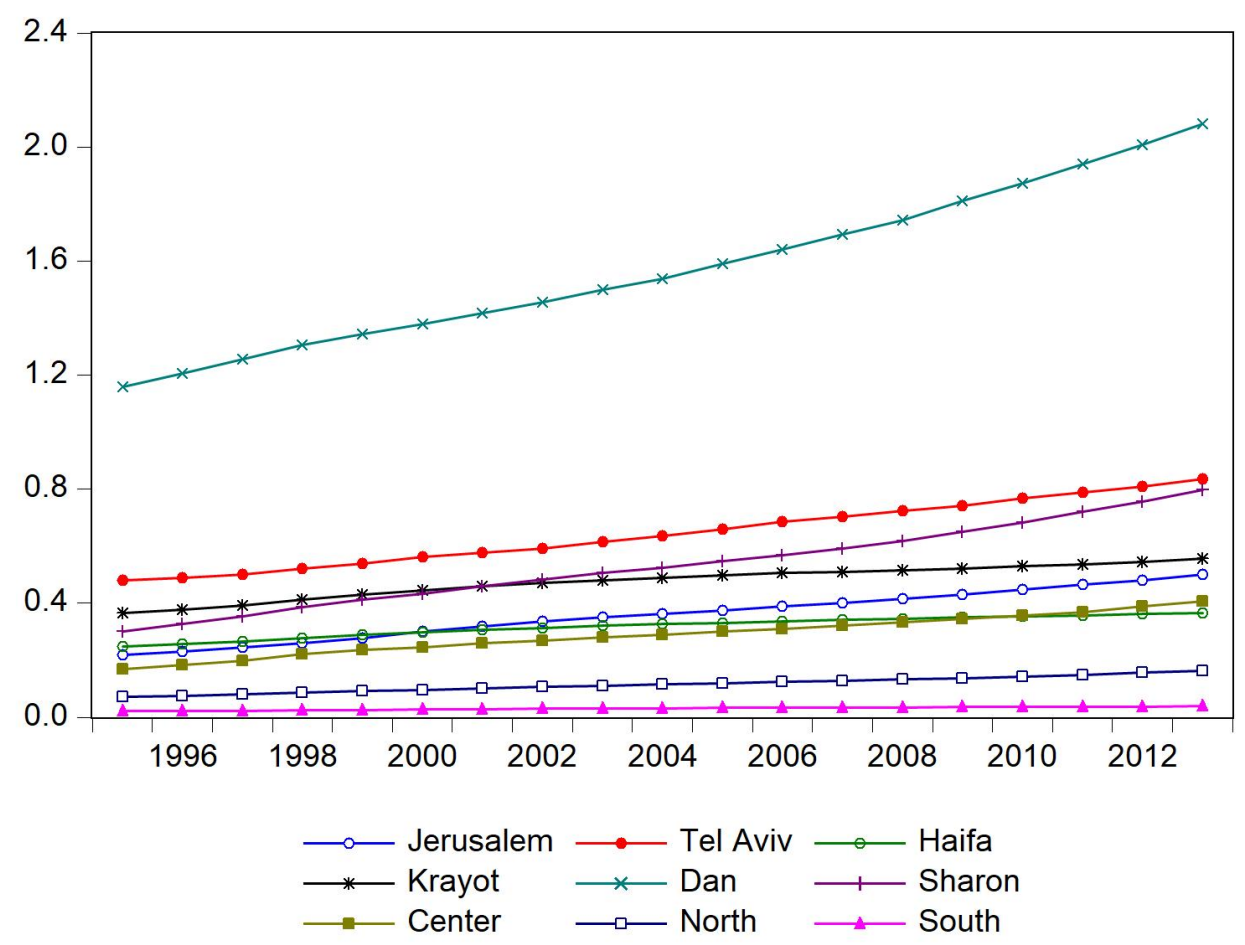

Figure 1. Housing Stock Land Reserves Ratio

construction has been on public land). Land is offered in low demand areas instead of high demand areas, causing the 'crowding-in' of private land. Their study also shows that the stock of public land is not managed effectively causing massive private sector crowd-in when a demand shock occurs.

The shares of housing stock in the land reserves from 1995 to 2013 in Israel's 9 regions are plotted in Figure 1, which shows that land reserves are relatively plentiful in the periphery than center. In the central regions such Gush Dan and Tel Aviv, land reserves has been steadily decreasing in the last two decades. Especially in Gush Dan (As shown in Figure 1, plotted in green), the land available to build is only a half of the house already built in the recent years. The demand for housing is concentrated in certain areas of Israel and must be aligned with the targeted areas of large-scale housing programs. While increasing the number of housing units reduces the housing shortage, the location of newly built housing needs to synchronizes with the location choice of the population. ${ }^{2}$

There are at least two reasons to explain why the supply of housing in Israel is insufficient. The first reason is the conflict between land ownership centralization and planning process decentralization. The second reason is due to the inequality in fiscal revenue among the local authorities.

\subsection{Land Ownership Centralization and Planning Process Decentralization}

Israel has traditionally possessed a positive sentiment towards top-down regional planning, although this sentiment has been overshadowed by national-scale planning,

2 In Israel, large scale housing programs usually focus on development of state-owned land which constitutes about $93 \%$ of national land area. However, policy makers must consider that the remaining $7 \%$ of land that is not randomly distributed across the country. 
Table 1: Planning Stages and the Average Years Required

\begin{tabular}{|c|c|c|}
\hline Stage & Responsible Entities & $\begin{array}{c}\text { Average Years } \\
\text { Required }\end{array}$ \\
\hline 1. Preparation by ILA & ILA & 1 \\
\hline 2. Discussion at Ministry of Interior & $\begin{array}{l}\text { Planning Administration of } \\
\text { Ministry of Interior }\end{array}$ & 5 \\
\hline 3. Preparation for tender & ILA & 1.5 \\
\hline 4. Auction & ILA & 0.5 \\
\hline 5. Building permit issued by local authority & Local Committees & 3 \\
\hline 6. Start construction & Contractors & $0-0.5$ \\
\hline 7. Complete construction & Contractors & 2 \\
\hline 8. Total & & $13-13.5$ \\
\hline
\end{tabular}

Source: Annual Report 2014, Bank of Israel, Table 7A3.

partly justified by the argument that given its small size, the whole country should be regarded as a single metropolitan region. One of motivations for governmental land control in Israel is to reduce inefficiencies generated by market failures and to ensure a more equitable distribution of the means of production. But in practice, the ILA land allocation scheme may cause other inefficiencies, caused by ineffective governmental decision-making and bureaucratic restrictions [7] . These problems may lead to slow and inefficient supply of land when there is persistent increasing demand over both space and time [8], [9].

Besides the delay in land planning procedure, the intentional delay could be result from the inconsistency of projection between central planner and local authority. In the decision making process public officials have the ability to demand economic rent in exchange for their decisions. According to a Bank of Israel report from 2013, the delay in the provision of residential housing is caused by the local and regional committees, "there are a number of indications that the delay in granting permits in the last year depends mainly on the local committees and not the entrepreneur, and therefore the decline in the number of permits is the source of the fall in the number of construction starts and not the reverse" (Bank of Israel, 2013a , p. 65).

The ILA provides the government with political control over land use in the long-run. On the approval of planners in the Ministry of Interior, ILA auctions these land reserves to private building contractors (Table 1, stages 3 and 4) who then apply for building permission from the local authority (stage 5), which decides on building intensity (high versus low-rise). The terms of the auction usually involve an element of subsidy in favor of the contractors. For example, the government may cover all or part of the development costs, and it may provide financial guarantees. Finally, it takes time to for contractors to organize and build (stages 6 and 7). The total process takes about 13-13.5 years. [10] simulate the land planning process using Israeli regional data and insert it into spatial a general equilibrium framework. They find that increasing land availability for housing construction and reducing planning time increases the affordability of housing.

Until 2015, the government agencies that were involved in housing worked mainly independently of each other. In order to solve the housing crisis, the national government decided to concentrate different government agencies relevant to housing production under the housing headquarters within the Ministry of Finance (Planning Administration, 2016). Although the tendering process is between the developers and central government, local authorities have right to determine land use, potential conflict of interest may exist between local authority and central government.

Most land policies in Israel focused on state-owned land, since the vast majority of land in Israel is publicly owned $(93.6 \%)$. The land tendering revenue goes to the central 
tax share.png

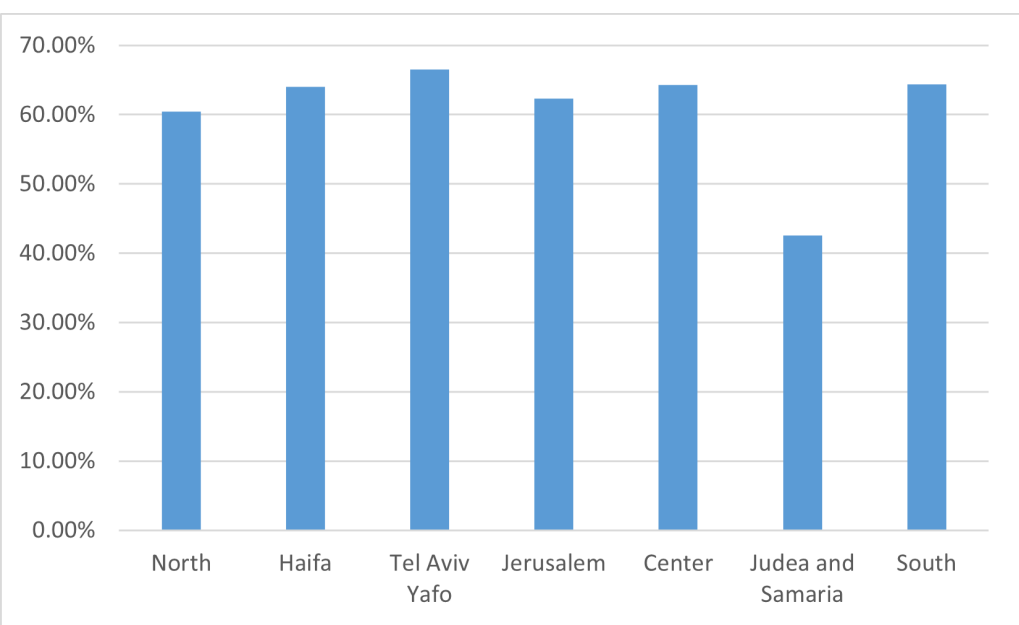

Notes: According to the Israeli Cent ral Bureau of Statistics, 2013 at 2013 prices

Figure 2. The Share of Municipal Rates in all Locally Generated Income by Regions(2007-2011)

government and returns to the local authorities indirectly through central government support (over 200 local authorities). The local authorities receive annual balancing budget support form central government as the budget balancing grant is part of the government assistance that is intend to balance between each local authority's normative level of expenses. It is determined by the central government and the local authority's potential revenue aiming to provide the residents basic services. ${ }^{3}$

Conflicts of interest arise when the central land plans deviate from the development target of the municipalities. The central government tends to bailout localities in financial distress, localities that repeatedly deviate from balanced budget constraints are able to extract transfers from other more financially responsible localities. Hence, a common pool practice behind the financing of local expenditures creates strong incentives for local officials to overspend. This is known in the literature as the soft-budget constraint problem following the seminal work of Kornai (1979).

The only independent revenue from land for local authorities is the property tax (Arnona). As this is the main source of revenue for local governments, it is important to ascertain how the introduction of such a tax changes the preceding results. For example, as shown in Figure 2, municipal rates payments in the municipality of Tel Aviv constituted $75 \%$ of its locally generated revenue in 2011 . The property tax system in Israel is a non ad valorem tax. Instead of direct assessment, the property tax rate is based on the physical size of a property, location and existing use rather than on any discrete estimate of open market value [11]. In order to build a theoretical model, I still treat 'Arnona' as a quasi ad valorem tax, as [12] provide statistical analysis suggesting that property value is the most significant predictive variable of the tax.

\subsection{Heterogeneity in Municipal Property Tax}

Whether fiscal centralization improves the fiscal efficiency of the municipalities is a controversial issue. [13] show that centralization program implemented in Israel in 2004

3 Until the middle of the 1990s, the size of this grant was set in negotiations between the Israeli Ministry of Interior and the local authorities. In 1993, within the framework of the Suary Committee 's recommendations, criteria were set for the first time for allocating budget balancing grants. Despite the committee 's recommendations, issues of consistency arose, such as providing too much assistance to the smaller local authorities and insufficient attention to the local authority's socioeconomic status. In the wake of that, in 2000, a public committee was appointed, headed by Yaacov Gadish, which determined a formula to allocate the grants that tried to balance between the need to guarantee basic services to residents and to create a system of incentives to encourage local authorities to operate more efficiently. The Gadish formula limited the maximum amount of the grant per person as a function of two conditions: first, that the grant not exceed the limit set for the maximum expenditure per person; and second, a minimum independent revenue per person was set. 
Source: Carmen database - the Israel Tax Authority's database of real-estate transactions, the Israel Tax Authority, and the Israeli Central Bureau of Statistics

Figure 3. Average Price Per Square Meter(NIS) by Region 2003-2012

Source: the Israeli Central Bureau of Statistics, 2013, at 2013 prices.

Figure 4. Average Municipal Rates Per Square Meter (NIS) by Region 2007-2011

brought a substantial decrease in municipalities' expenditures and an increase of local property tax collection. [14] find that high dependence on central government transfers exacerbates political budget cycles, while tight monitoring eliminates them. Although property tax contributes most of the fiscal revenue for municipalities in Israel, since most land is public owned, the land planning and revenue distribution process in Israel is still highly centralized. [7] have documented the inefficiency of public ownership in Israel based on two arguments: that monopolies are inherently inefficient compared with competitive markets and that public administration and decision-making are inevitably less efficient than private profit making organizations.

[3] find that residential house prices grow rapidly relative to the commercial prices. This fact is possible because the local authorities in Israel face a negative incentive to increase the supply of housing and to add residents to the area s under their jurisdiction. An examination of the price of a square meter in real estate transactions for commercial purposes in the Carmen database Figure 3, a database produced by the Israel Tax Authority of all transactions reported during 2000 to 2013, yields a surprising result. While the price of a square meter of built area intended for residential use in cities in the Jewish sector rose by $40 \%$ during 2006-2013, the price of a square meter of built area intended for commercial use did not change significantly during this period.

Municipal property taxes are collected from two main sources: property tax on area zoned as residential and non-residential land uses. Figure 4 depicts the municipal rates on different land use by regions in year 2013. The municipal rates per square meter for businesses is four times that of the municipal rates for residences in municipalities in the Tel Aviv region, while it is three times more in the Jerusalem and central regions. Local authorities prefer not to absorb populations that need expensive services and whose contributions to the authorities' revenue is low [15]. According to [16] this situation is expressed in local authorities manipulation of housing and construction plans.

The model in section 3 explains this fact. When there are a large number of municipalities, property tax rates are determined in a competitive equilibrium, such that each local public authority provides an optimal amount of public services to accommodate residents and workers. The agglomeration rent encourages local authorities to promote commercial development and make residents less sensitive to local taxation in the central area.

\section{Conceptual Framework}

The modern approach to urban land use has its origins in the work of [17], [18], and [19], which is built around the key observation that commuting cost differences within an urban area must be balanced by differences in the price of living space. When there is a single residential land use, all the firms locate at the CBD, and whose size is assumed to be zero. The residential area expands with the number of households and with the income and/or the utility level of the households. The city is depicted as an interval on the strait line with one unit of land available at each location $x$. Since the shape of the city is symmetric, let $\bar{x}$ denote the city's boundary. 


\subsection{Households}

Assumed that all the households in the city have the same characteristics (i.e., the same tastes and the same income) at each time. The utility function for households is identical $u(z, \bar{h}, G)$, where $\bar{h}$ represents the land consumption, which is fixed and $z$ the consumption of a composite good, $G$ is the amount of public goods provided by the local authority. The utility function is assumed to be well-behaved, i.e. the function is continuous and increasing at all $z, \bar{h}, G>0$ and satisfying $u_{1}, u_{2}, u_{3}>0, u_{11} \cdot u_{22}, u_{33}<0$. Furthermore, each household supplies one unit of labor and gets income of $y$ in return, and the composite good is imported from outside the urban area at a constant price normalized to 1 . The composite local public service $G$ is provided equally and enters positively into individual utility functions.

Let $z(\bar{h}, \underline{u}, G)$ the amount of numeraire $z(\underline{u})$ private goods and allow him or her to enjoy utility $\underline{u}$ given $G$ amount public goods. The household's budget is expressed as

$$
y=\Psi(x) \bar{h}+\kappa \Psi(x) \bar{h}+c|x|+z(\bar{h}, \underline{u}, G)
$$

where $c$ is the unit commuting cost, the expense of commuting is a linear function of distance to the center $c|x|$. The objective of a household is to choose a residential location $x$. $\Psi(x)$ is the rent per unit, the property tax is an ad valorem tax on the rent of houses $\Psi(x) \bar{h}$, let $\kappa$ denote the property tax rate.

The bid rent function for housing and for residential land $\Psi(x, \underline{u})$ is the maximum price a resident can pay for one unit of house consumption at each location $x$ while consuming the amount of numeraire $z(\underline{u})$ that allows him or her to enjoy utility $\underline{u}$ and while also satisfying the budget constraint:

$$
\begin{gathered}
\Psi(x, \underline{u}, G)(1+\kappa) \bar{h}=y-c|x|-z(\bar{h}, u, G) \\
\Psi(x, \underline{u}, G)=\frac{y-c|x|-\bar{h} u}{(1+\kappa) \bar{h}}
\end{gathered}
$$

\subsection{The Public Sector}

The local authority's role is to provides a congestible ${ }^{4}$ local public good to its residents (which has not to be pure). We may assume the quality of public service $G$ is a function of population $N$ and total expenditure $c_{g}$. The consumption of public services is independent of location within the city. The simplest case to consider is $G=\frac{k c_{g}}{N}$, the quality of public service is a linear function of total expenditure divided by the population. In the static model, expenditure $c_{g}$ of public service is funded by ad valorem tax on rent. Given the property tax rate $\kappa$, without issuing debt, the fiscal budget is the total rent of houses on land occupied by the residents $\left[-x^{*}, x^{*}\right]$,

$$
c_{g} \leq 2 \kappa \int_{0}^{x^{*}} \Psi(t, x) d x
$$

The property tax has is a non-distorted tax if $\frac{\partial u}{\partial \kappa}=0$, let aggregate differential rent (ADR) $A D R=2 \int_{0}^{x^{*}} \Psi(x, \underline{u}, G) d x$ then

$$
\begin{gathered}
\frac{\partial u}{\partial \mathcal{K}}=-u_{1} \Psi(x) \bar{h}+u_{3} \frac{k}{N} A D R(N)=0 \\
\frac{u_{3}}{u_{1}}=\frac{\Psi(x) \bar{h}}{k A D R(N) / N}
\end{gathered}
$$

\footnotetext{
4 Congestible public goods are those public goods which become rival as more and more people consume them, such as highways.
} 
which is a spatial version of the Samuelson condition for optimal provision of a public good: The sum of the marginal benefits (measured by the rate of substitution $\frac{u_{3}}{u_{1}}$ ) over all households in the city must equal the marginal cost of the public good.

In the dynamic model, both land selling (leasing) and the property tax can be modeled as the revenue of the local authorities depending on the distribution of land ownership. If a city can expand without a boundary, the total revenue $T R(t)$ for the city is the sum of revenue from land selling at the city's border $x^{*}(t)$ and the total property tax on the rent of houses ever built. The next subsection describes a scheme when the city is growing.

\subsection{Urban Growth}

In this subsection, I describe the dynamics of city expansion based on the framework of the [1], [20]. I assume that land is owned by the local authority and can be sold once. The identical utility level of households in the national economy is given as a function of time, $\underline{u}(t),(0<t<\infty)$. Migration is free between the city and the rest of the nation. Thus, the utility level of the households in the city is always adjusted to that of the national economy through migration, and housing rents are determined such that the utility level of the households in the city is the same as the utility level of the national economy. Developers determine the optimal construction plan of houses under these equilibrium housing rents.

$$
\Psi[x, u(t), G]=\frac{y(t)-c|x|-\bar{h} \underline{u}(t)}{(1+\kappa) \bar{h}}
$$

Assume the land owners have perfect-foresight, which means developers have complete knowledge of the future evolution of prices in the urban economy. Developers determine, for each unit of land at each distance $x$, the optimal time $t^{*}$ at which the land is converted from agricultural use to residential use. It is assumed that developers have perfect foresight about the future time path of housing rent, the cost of conversion is $B$.

$$
p(x, h, t) \equiv \int_{0}^{t} A e^{-r(\tau-t)} d \tau+e^{-r t} \int_{t}^{\infty} e^{-r(\tau-t)}(1+\kappa) \Psi[x, \underline{u}(\tau)] d \tau-B e^{-r t}
$$

When the land is privately owned, the transaction of land means full transaction of property rights. The price is the total discounted rent income from the transaction time till infinity. In countries where land is owned by the state, the transaction of land means transaction of ownership (partial), which means the land is usually leased for a long period $^{5}$. The price of land equals the sum of discounted rent income till the tenure is over

$$
p(x, h, t) \equiv \int_{0}^{t} A e^{-r(\tau-t)} d \tau+e^{-r t} \int_{t}^{t+\text { Tenure }} e^{-r(\tau-t)}(1+\kappa) \Psi[x, \underline{u}(\tau)] d \tau-B e^{-r t}
$$

For simplicity, in our model I assume the tenure is infinitely long, and the land is "sold". The land owners choose the best time $t^{*}$ to convert land from agricultural use to residential use. The first-order conditions for $t^{*}$ is

$$
\left.\frac{\partial p}{\partial t}\right|_{t=t^{*}}=0
$$

Which gives to

$$
(1+\kappa) \Psi\left(t^{*}, x, G\right)=A+r B
$$

\footnotetext{
5 For example "Ownership" of real estate in Israel usually means leasing rights from the ILA for a period of 49 or 98 years. In practice though the rights granted to leaseholders under the current Israeli leasehold system closely resemble full property rights, urban land, though formally still the property of the ILA, has for all practical purposes been privatized, especially since leases are now renewed automatically without any further payment. In China all land is owned by the state or by collectives. After carrying out the opening policy in 1978, China transformed its planned economy system into a socialist market economy system, and adopted a land use rights tenure system similar to the land leasehold tenure system in Western countries.
} 
Condition (11), determines $t^{*}(x)$, the conversion date and dwelling size at a given location $x$, which inversely determines the urban fringe $x^{*}(t)$ as a function of time $t$. The left hand side of equation (11) represents urban land rent(housing rent per acre minus annualized development cost. At the boundary urban land rent equals to the value of agriculture land. It is not difficult to obtain from equation (11)

$$
y\left(t^{*}\right)-c x-\bar{h} u\left(t^{*}\right)=(A+r B) \bar{h}
$$

The city's border $x^{*}$

$$
x^{*}(t)=\frac{y(t)-(A+r B) \bar{h}-\bar{h} u(t)}{c}
$$

Since the residents of the city locate at an interval of a straight line, at time $t$, the total population is $N(t)$ is twice the urban fringe $x^{*}$ divided by the house size $\bar{h}$,

$$
N(t)=\frac{2 x^{*}(t)}{\bar{h}}=\frac{2 y(t)}{\bar{h} c}-(A+r B)-u(t)
$$

Equation (3) determines the gradient of the rent

$$
\frac{\partial \Psi(t, x)}{\partial x}=-\frac{c}{(1+\kappa) \bar{h}} x>0
$$

Combining equation (11), the border condition indicates $\Psi\left[t, x^{*}(t)\right](1+\kappa)=A+r B$, which in turn implies that the rent function as a function of location $x$ and time $t$, is

$$
\Psi(t, x)=A+r B+\frac{c}{(1+\kappa) \bar{h}}\left[x^{*}(t)-x\right], x<x^{*}(t)
$$

Assumption 1. The initial condition $y(0)-\bar{h} u(0)>(A+r B) \bar{h}$, i.e. $x^{*}(0)>0$. The initial condition guarantees that at time 0 the city has positive size.

Proposition 1. If income and public services are growing faster than the speed of reserve utility multiplied by the dwelling size $\bar{h}$, the city is on the path of expansion, given the initial condition. I provide a brief proof of the above results as follows. The speed of city's expansion is the first order derivative $d x^{*}(t) / d t$

$$
d x^{*}(t) / d t=\frac{y^{\prime}(t)-\bar{h} u^{\prime}(t)}{c}
$$

Since the city is open, if the total local income $y(t)$ is growing faster than utility level $u(t)$ outside of the city, there are more people willing to move to the city. The more people that move to the city, the more land is converted from agricultural use and the more the city border increases. In equilibrium, household's location choice is on the optimal development path and the size of dwelling is not effected by public finance. The city is growing at a certain speed without reverse development, $\frac{d x^{*}(t)}{d t} \geq 0$. At time $t$ the land at the fringe between urban and agriculture is converted and sold. Let $\Pi(t)$ denote the net income from conversion and selling the land at city's fringe $x^{*}$ which equals to price of land minus the cost of conversion and value of agricultural use.

$$
\Pi\left[x^{*}(t), t\right]=p\left[x^{*}(t), h, t\right]-\frac{A}{r}-B
$$

It is not difficult to obtain from eq.(8) the net income from conversion and selling the land is the value of future rent increases resulting from growth..

$$
\Pi\left[x^{*}(t), t\right]=2 \frac{1+\kappa}{r} \int_{t}^{\infty} \Psi_{\tau}\left[\tau, x^{*}(\tau)\right] e^{-r(\tau-t)} d \tau
$$


Proposition 2. The net revenue from conversion and selling of the land positively is increasing with the speed of urban growth $N^{\prime}(t)$, commuting cost $c$ and decreasing with the interest rate $r$, and the independent of the property tax $\kappa$.

A brief proof of the above proposition is as follows. First, the population at time $t$ is twice the distance from the urban fringe to the center divided by house size

$$
N(t)=\frac{2 x^{*}(t)}{\bar{h}}
$$

We substitute equation (16) into equation (19)

$$
\Pi\left[x^{*}(t), t\right]=\frac{2 c}{\bar{h} r} \int_{t}^{\infty} \frac{d x^{*}(\tau)}{d \tau} e^{-r(\tau-t)} d \tau
$$

Inserting the population into the equation above and integrating it by parts yields,

$$
\begin{gathered}
\Pi\left[x^{*}(t), t\right]=\frac{c}{r} \int_{t}^{\infty} N^{\prime}(t) e^{-r(\tau-t)} d \tau \\
\Pi\left[x^{*}(t), t\right]=\frac{c}{r}\left[r \int_{t}^{\infty} N(\tau) e^{-r(\tau-t)} d \tau-N(t)\right]
\end{gathered}
$$

The expression of (22) indicates that the net revenue from land selling is the sum of the discounted population growth from $t$ to the infinite future. By assumption, the city is growing at a certain speed without reverse development, $\frac{d x^{*}(t)}{d t} \geq 0$, the net income $\Pi\left[x^{*}(t), t\right]$ is always non-negative. Therefore, the marginal effect of $\frac{d x^{*}(t)}{d t}$ and $c$ on $\Pi\left[x^{*}(t), t\right]$ is easily determined to be positive and $r$ to be negative. The proposition indicates the revenue from selling land depends on the speed of population growth is independent of population size and tax rate. This fact enriches local public goods models, namely, land capitalization. Capitalization means that the price of land embodies the benefits and costs of public services incurred by the residents. Hence, capitalization provides a natural measure of social surplus or willingness to pay for an increase in local public goods. In countries that undergo urbanization or population growth process, land selling (leasing) revenue serves another source of land capitalization which is future population growth. A few examples illustrate how the growth pattern affects the land selling (leasing) revenue.

Linear Growth: Consider a city that expands at a constant speed $\alpha$ without boundary, $N_{t}=N_{0}+\alpha t$, the city fringe expands at the speed of $N^{\prime}(t)=\alpha$. Then the total revenue during time $\Delta t$ from land selling is

$$
\begin{gathered}
\Pi=\frac{c}{r} \int_{t}^{\infty} N^{\prime}(\tau) e^{-r(\tau-t)} d \tau=\frac{\alpha c}{r^{2}} \\
\Pi(\Delta t)=\frac{\alpha c}{r^{2}} \frac{\Delta N}{\alpha}=\frac{\Delta N c}{r^{2}}
\end{gathered}
$$

The above result shows if the city is growing at constant speed the net revenue from land selling equals to population increase multiplied by the transportation cost, while the interest rate has a strong effect on the revenue.

Exponential Growth: Consider a city that expands at a exponential speed $\alpha$ without a boundary, $N_{t}=N_{0} \exp (\alpha t), \alpha \leq r$ to avoid arbitrage, the population is growing at the speed of $N^{\prime}(t)=N_{0} \alpha e^{\alpha t}$. Then the total revenue during time $\Delta t$ from land selling is

$$
\Pi=\frac{c}{r} \int_{t}^{\infty} N_{0} \alpha e^{\alpha \tau} e^{-r(\tau-t)} d \tau=\frac{c N_{0} \alpha}{r(r-\alpha)} e^{\alpha t}
$$

Stochastic Growth One of the most important applications of [1]'s model is when the demand is under uncertainty. Land is considered to be risky asset with return of housing rent after the land is converted into residential use. Landowners choose the conversion time to maximize expected profits or the value of land, which resembles an option on finance 
asset. [21] show that uncertainty i) delays the conversion of land from agricultural to urban use, (ii) imparts an option value to agricultural land, (iii) causes land at the boundary to sell for more than its opportunity cost in other uses, and (iv) reduces equilibrium city size. The land selling revenue can be considered as a sequence of real options at the reservation price of agricultural rent. The valuation of these assets is more complicated than modeling the value of a piece of land in one shot. At least, some intuitive conclusions can be drawn. First, uncertainty increases the risk premium and increases revenue from from land sales. Second, uncertainty delays land conversion and subsequently population growth which decreases price.

In practice, cities can not expand without a boundary. As land becomes scarce prices are driven up. Land depletion also increases the risk of conversion since the less elastic the land supply is, the more drastically prices change.

\section{Empirical Results}

This section serves as the empirical application of theoretical models in the last section. I use survival analysis to study the determinants on land plans acceptances such as land reserves and local authorities' fiscal status when land tendering revenue is centralized. Despite the discussion on casual relations between land supply and planning process delay in Israel and elsewhere there is not, to the best of our knowledge, definite empirical evidence testing the effect of municipality's fiscal status on central land planning using survival analysis.

\subsection{Fiscal Independence}

In countries where land is owned by the public, different forms of allocating land sale/lease revenues exist. For example, in China local governments have large autonomy to allocate revenue from land sales. In Israel, however, local authorities are less independent in allocation income from land tendering. The first issue concerning such land tenure systems arises when the interests of local and central government are not consistent. For example, when income from land selling does not directly enter the account of the local authority, since the target of the local authority is to provide public goods to attract the population. I define variable fiscal independence FIS IND as the share of local generated revenue to the total municipal revenue and the share of residential tax revenue in total property tax RES RAT.

$$
\begin{aligned}
& \text { FIS IND }=\frac{\text { local municipal income }}{\text { total municipal income }} \\
& \text { RES RAT }=\frac{\text { residential tax revenue }}{\text { total tax revenue }}
\end{aligned}
$$

The graph on the left in Figure 5 plots the relation between new houses authorized during year 2010-2015 and land reserves in logs. There appears obvious a strong positive correlation between these two variables since the available land is the prime input for construction. The marker sizes are proportional to city's population level, the OLS fit line is included. The larger markers lie above the fit line but evenly on left and right sides of the $x$-axis which indicates the strong correlation between city size and new construction. However no significant correlation between city size and land reserves. The graph on the left in Figure 5 plots construction starts for commercial purpose on the vertical axis and fiscal independence on the horizontal axis. The positive slope of the fitted line shows there are more commercial buildings to be built in municipalities where local tax revenue contributes higher percentage. 


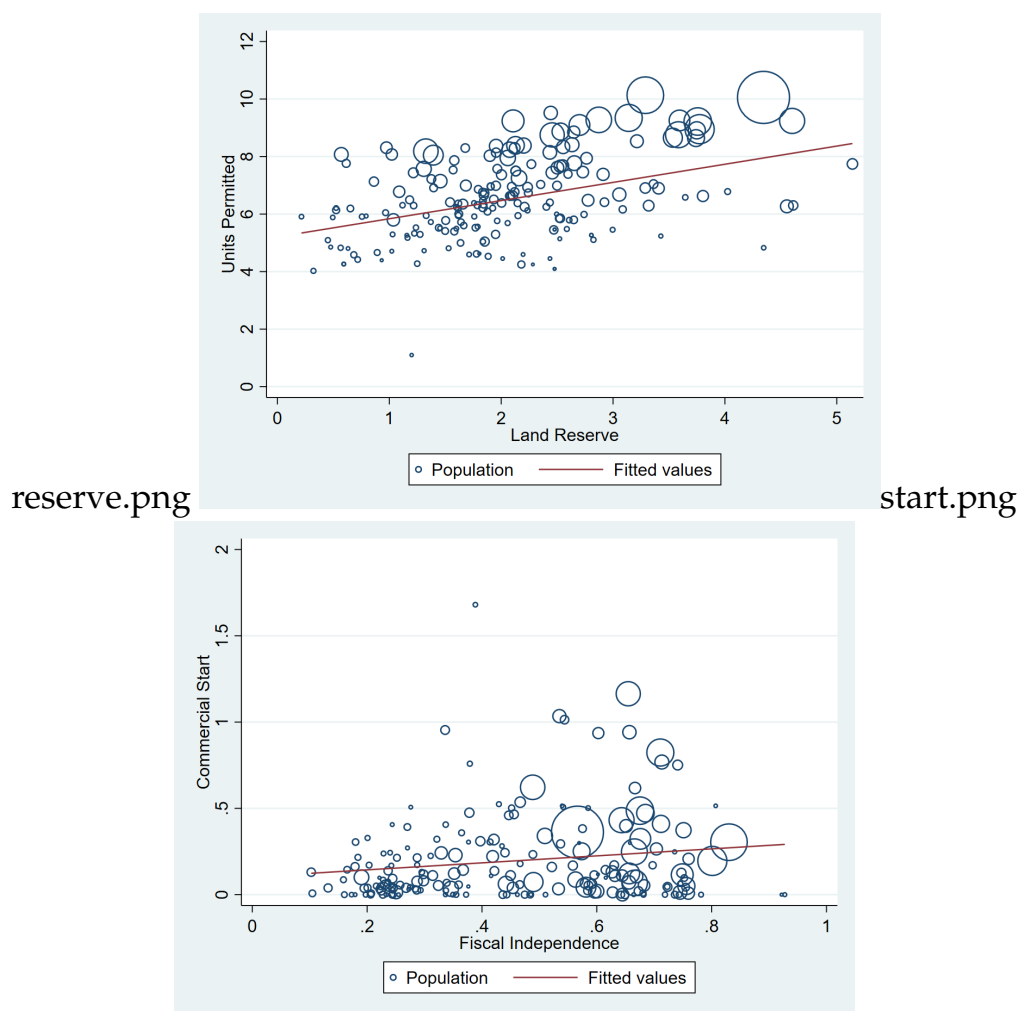

Note: For each panel in this figure (each corresponding to a pair of variables), there are 195 data points, each representing a municipality in Israel. I estimate OLS regressions of the variable on the vertical axis on the variable on the horizontal axis. Significance level are all below $5 \%$ and the OLS fit line is included. Data points are weighted by municipality's population.

Figure 5. Land Reserves and Construction in 2015 


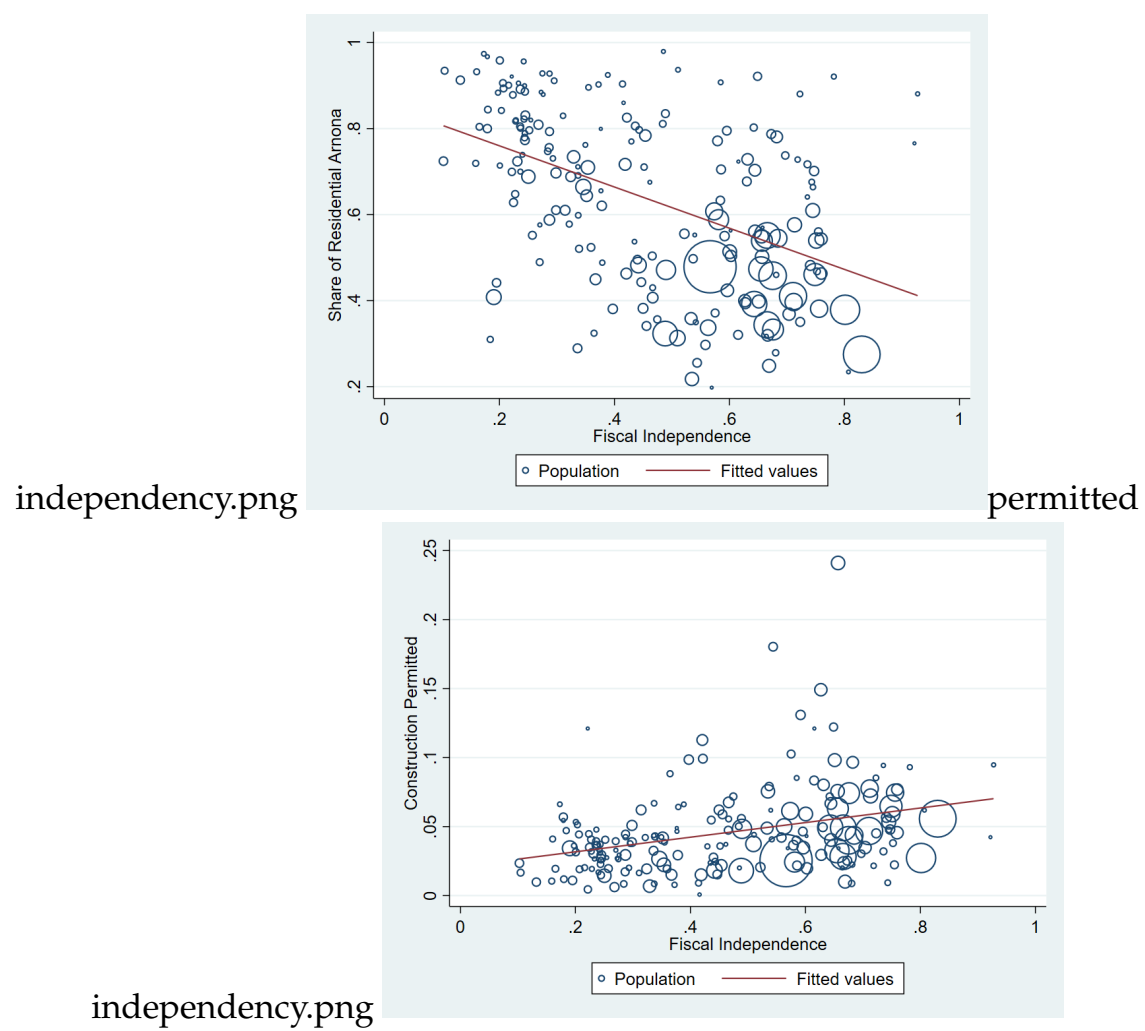

Note: For each panel in this figure (each corresponding to a pair of variables), there are 195 data points, each representing a municipality in Israel. I estimate OLS regressions of the variable on the vertical axis on the variable on the horizontal axis. Significance level are all below $5 \%$ and the OLS fit line is included. Data points are weighted by municipality's population.

Figure 6. Fiscal Independence and Housing Starts 2015 
pendence on the horizontal axis. There appears in a general strongly negative correlation between share of residential tax revenue and fiscal independence. In other words, the municipalities with more revenue from commercial property tax are less dependent on central government support. The marker sizes are proportional to city's population level, which shows that the fitted negative correlation is a better prediction for larger cities. Moreover large most cities are located in the right half of the graph. This is no surprise given that large cities have more commercial buildings than small cities. The negative correlation indicates that municipalitys' local revenue may largely depend on their revenue through property tax from commercial buildings, especially for large cities.

The graph on the right in Figure 6 plots residential building units permitted during year 2010-2015 on the y-axis, and fiscal independence on the $x$-axis. There shows a significant positive relation between these two variables. Municipalities with the ability to generate more local tax revenue are willing to build more houses to accommodate new residents. To illustrate this idea, I consider each municipality as a firm with a marginal cost increasing production function, the different tax rate schedules are depicted in Figure 7 and Figure 8.

In each diagram, I plot the marginal and average cost of supply municipal service (as highlighted by the blue solid and dash lines on the graph) and marginal local and total revenue (as highlighted by the red and orange dash lines on the graph) on the vertical axis and the number of residents of the municipality on the horizontal axes. Each municipality faces a competitive tax rate which is determined exogenously ${ }^{6}$ to provide a municipal service. To avoid the soft budget constraint problem, central government sets the maximum amount support per capital for local authorities to cover their expenses if local tax revenue is not enough. At different levels of marginal total revenue (highlighted by the orange dash line on the graph), the optimal size of the population that the municipality manages to accommodate at equilibrium will be the point where the marginal cost (highlighted by the blue solid line on the graph) per resident equals the marginal revenue per resident. Beyond this point, the municipality will want to halt the growth of its population.

Figure 7 depicts a scenario when the municipal revenue is above the break even level $P$ which is the point where the marginal cost line crosses the average cost line. The local public service is at break even level because the marginal total revenue will exactly offset the marginal cost of local public services provision. Above point $P$, the municipality is able to accommodate more residents and generate fiscal surplus, since the marginal revenue is higher than average cost. If there is no central government support, the maximum population for the municipality to accommodate is $N_{0}$. The maximum population the municipality is able to accommodate is $N_{2}$, when it get the maximum amount from the central government support. If the population increases from $N_{1}$ to $N_{2}$, the total fiscal surplus increases from the blue area in to the gray area, with surplus per capita increasing from $A N$ to $B M$. When the local authorities have sufficient local revenue, they tend to attract population and are less likely to fall into financial distress.

Figure 8 depicts a scenario when the municipal revenue is below or at the break even level $P$. When population is at $N_{1}$, the marginal total revenue line crosses the marginal cost line at point $A$. The municipality's average revenue can't cover the expense per capita. The area in gray plots the amount of the municipal deficit when population is $N_{1}$. To avoid a deficit, the local authorities is able to increase its population to $N_{2}$. However beyond this point, central government support reaches to its limit. More residences will aggravate the local authority's deficit burden. The local authorities with insufficient local revenue tend to suppress population growth and likely to fall into financial distress.

6 In Israel, each municipality design a tax ordinance within its jurisdiction declaring the rules of taxation and exemptions. These ordinances state differential rates per sq. meter for classified zones within its municipal boundaries and building categories that characterize its housing stock. While central government in Israel sets the tax ordinance, it is not aware of the different municipalities' expenses to a large extent. In section 5.3, we show in fact these rates are determined in spatial equilibrium. 


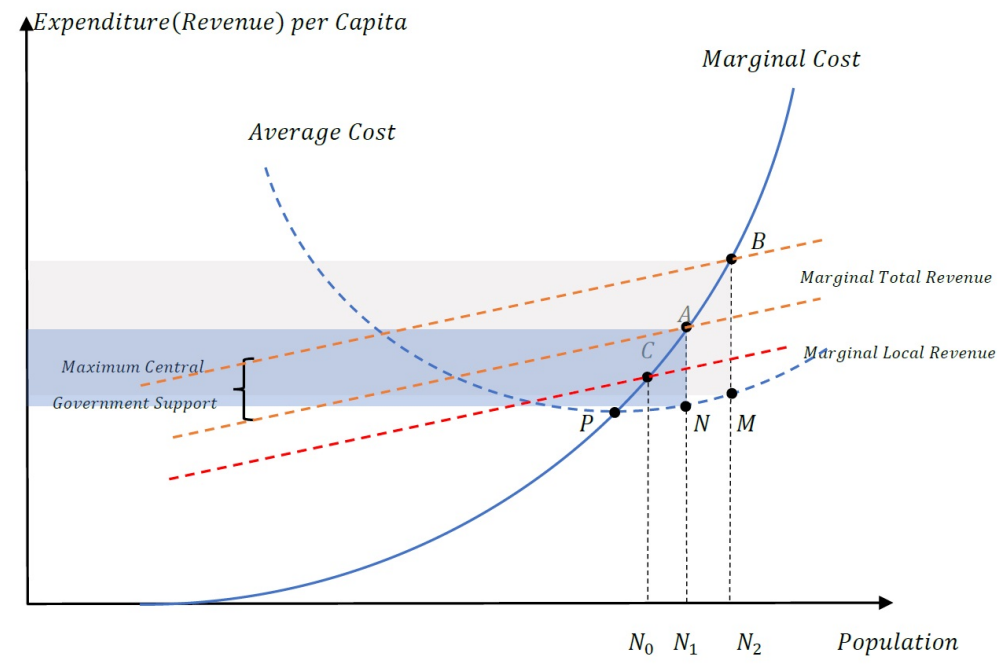

Figure 7. Municipality with Balanced Budget

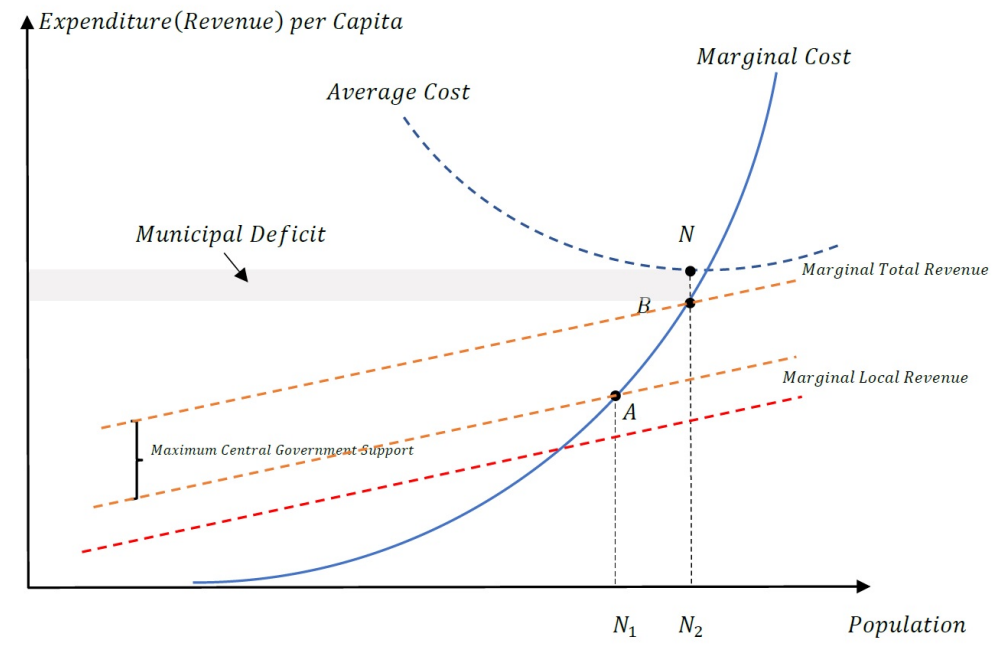

Figure 8. Municipality in Fiscal Distress 
Table 2: Summary Statistics on Land Planning in Tel Aviv 2003-2014

\begin{tabular}{|c|c|c|c|c|c|}
\hline Group & Variable & Symbol & Unit & Mean & STD \\
\hline \multirow{6}{*}{ Project } & Number of planning days & $D A Y$ & Days & 529.9 & 454.7 \\
\hline & Change in housing units & $U N$ & Housing Units & 61.06 & 706.4 \\
\hline & Commission load & $\angle O A D$ & Plans & 254.8 & 69.23 \\
\hline & Moratorium & MORA & Dummy & 0.266 & 0.442 \\
\hline & Objection & $O B$ & Dummy & 0.203 & 0.402 \\
\hline & Std. of planning time & $\sigma_{D A Y}$ & Days & 558.3 & 478.0 \\
\hline \multirow{9}{*}{ Municipal } & Land depletion & $D E P$ & $\%$ & .0261 & .0329 \\
\hline & Population Growth & $\triangle P O P$ & Thousands & 3.21 & 5.57 \\
\hline & Price Growth & $\Delta P$ & $\mathrm{NIS} / m^{2}$ & 1103.7 & 1744.1 \\
\hline & Income Growth & $\triangle I N C$ & $\mathrm{NIS} / m^{2}$ & 99.26 & 263.8 \\
\hline & Employment Growth & $\triangle E M P$ & $\%$ & -0.00353 & .0761 \\
\hline & Matriculation share & $E D U$ & $\%$ & 64.1 & 17.6 \\
\hline & Accumulated Deficit Per Capita & $D E F$ & NIS & -1108.2 & 905.3 \\
\hline & Share of Arab population & $A R A B$ & $\%$ & 1.05 & 1.73 \\
\hline & Average monthly income & $I N C$ & NIS & 7898.9 & 1816.4 \\
\hline
\end{tabular}

\subsection{Survival Analysis on Planning Time}

Survival analysis is a family of statistical tools appropriate for understanding and modeling the time to an event such as a strike and bankruptcy. That is, the dependent variable in survival models is the length of time to some event of clinical or theoretical importance. Classically, the event of interest was death-for that reason the statistical technique became known as survival analysis. Event history analysis is another commonly used term for the same method. The object here is to characterize the probability distribution for which planning time lasts, and, in particular, to investigate the hazard function associated with this distribution.

Using the data in [22], I reestimate the determinants of planning time in the Tel Aviv DPC (district planning commission), these determinants includes both municipality characteristics and DPC attributes.

The upshot of this is that municipal financial burdens must be taken into account when dealing with housing supply constraints. This section uses survival analysis to replicate the empirical evidence to illustrate the single land use model. This section revisits the claim that a causal link exists between the inflexibility of land-use planning and low elasticity of housing supply. A theoretical model of factors impacting district-level planning is presented alongside a model of the impact of planning delay on housing supply. The models are estimated for the Tel Aviv district using detailed data covering a 12-year period.

Table 2 displays the variables used in planning time models. The tables include variable definitions, measurement units and basic statistics. These variables can be divided into two groups. The first group contains variables in explaining the features of the plans, such as size of the plan $U N$ which is the change in housing units in the plan. $O B$ records whether the plan has been objected. MORA is the planning moratorium on the central parts of Israel was in effect ${ }^{7}$.

7 In August 2008, the Israeli government decided on a planning and land allocation moratorium in central parts of the country for the years 2009-2012 This decision aimed to promote the development of peripheral areas by decreasing development in high demand regions, in accordance with National Outline Plan \#35. As a result of the dramatic increase in housing prices, which started at the end of 2007, the government reversed the decision in July 2010. 
The second group of variables includes the features of local authority where the plans were proceeded, which are used to explain the municipal heterogeneous effects. These variables are helpful in explaining delays in the planning process driven by the municipalities. The price growth $\Delta P$ during the planning project $i$ is defined as the house prices in municipal $j$ when the project was accepted minus the house prices in municipal $j$ when the project was submitted. The population, income and employment growth are calculated by the same method. The land depletion of project $i, D e p_{i}$ in municipal $j$ is the land consumption divided by the land reserve at time plan $i$ was accepted which is calculated by formula as follow

$$
D E P=\frac{\text { Developable land } i\left(j, t_{\text {accepted }}\right)-\text { Developable land }_{i}\left(j, t_{\text {submitted }}\right)}{\text { Developable land } i\left(j, t_{\text {accepted }}\right)}
$$

$D E F$ measures the accumulated deficit per capita of municipalities which is the sum of deficit from the project was submitted until the project was accepted(rejected).

\subsection{Empirical Framework}

The definition of event is some type of qualitative change that can be determined as occurring at a relatively specific point in time. The event of interest here is plan approval and censoring occurs if an objection to the plan is lodged. To obtain an estimable model, it is necessary to specify the continuous probability functions in more detail. Let $S(t)$ be the survival function of planning, which is probability distribution of the plan being approval at time $t$. The function $f$ is the event density which is the rate being not approved per unit time. The hazard function is defined as the probability of approval at time $t$ conditional on not being objected until time $t$ or later (that is, $T \geq t$ ).

$$
\lambda(t)=-\frac{S^{\prime}(t)}{S(t)}=\frac{f(t)}{S(t)}
$$

Let $X_{i}=X_{i 1}, \ldots, X_{i n}$ be $n$ observations of $i$ th explanatory variables, which are summarized in Table 2. I specify the hazard rate for the Cox proportional hazards model as in the form

$$
\lambda\left(t \mid X_{i}\right)=\lambda_{0}(t) \exp \left(X_{i} \cdot \beta_{i}\right)
$$

$\lambda_{0}(t)$ is called the baseline hazard. The baseline hazard is common to all units in the population; individual hazard functions differ proportionately based on a function $\exp \left(X_{i} \cdot \beta\right)$ of observed covariates.

$$
\ln \lambda\left(t \mid X_{i}\right)=\ln \lambda_{0}(t)+X_{i} \cdot \beta_{i}
$$

For example, Figure 9 plots the non-parametric estimate of survival function $S(t)$ conditional on binary variable MORA. The x-axis is the number of days after the plan is submitted, the $y$-axis is the probability of not being accepted. The probability of not being accepted conditional on the plan being under moratorium is plotted in red, while the probability of under planning without moratorium is plotted in blue. As shown on the graph, the probability of not being accepted is significantly higher if the plan is is under moratorium after for a number of days. .

\subsection{Results}

I estimate the coefficients equation (32) using Cox's partial likelihood method. The results are presented in Table 3 . In all our specifications, plan characteristics have significant impacts on planning delay as expected. The interpretation of coefficients $\beta$ is different from the regressions using planning days as the dependent variable and their signs are opposite in general. The coefficients of the regressors measure the conditional marginal effect of the 


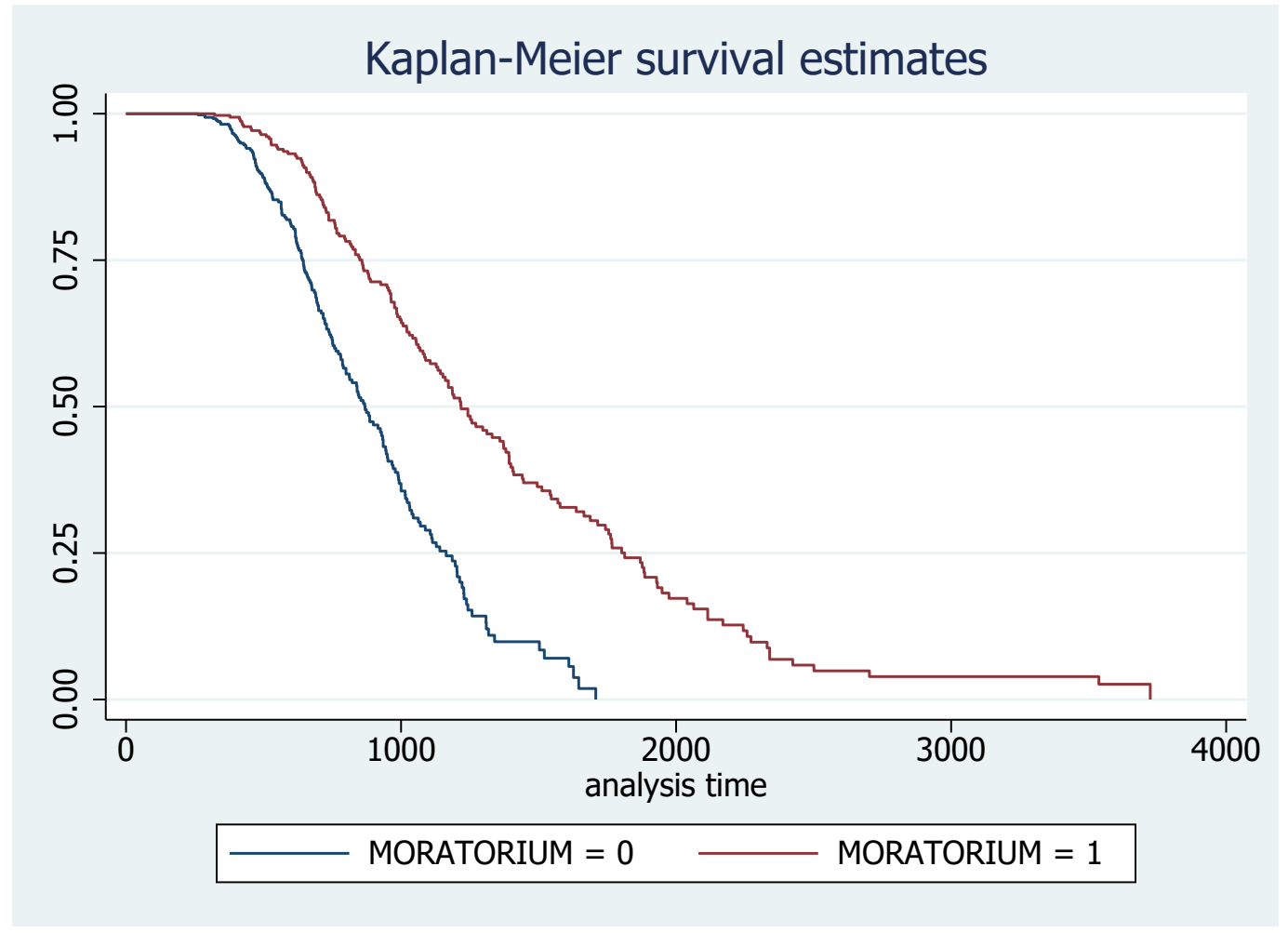

Figure 9. The Effect of Moratorium on Survival Functions

independent variable on the probability of approval at each time $t$. The findings show that size of the plan UN decreases the probability of approval, and MORA delays the planning process. While planning delay does not impact housing supply, planning time uncertainty has a negative impact on planning process which is indicated by the negative sign on $\sigma_{D A Y}$ in model 4.

The probability of approval largely depends on municipality and district planning commission characteristics, most of estimates are significant and consistent through all our specifications. First, the probability of objection and municipal is positively correlated with the growth of house prices. This finding is well supported by [22] that housing supply and prices are cointegrated in the long term and housing supply is influenced land planning process. Further, objection in planning reduces housing supply. Secondly, income growth increases the probability of plans being objected, since income growth is correlated with house price growth. These results suggest that rapid regional economic growth increases the amount of work in planning process by local authorities.

As expected, the coefficients on the the land depletion terms Dep in Table 3 are negative and highly significant. This indicates that projects in municipality with higher land depletion have a lower hazard rate of acceptance. The population growth $\triangle P O P$ has a significant effect in decreasing the probability of approval. However, employment growth $\triangle E M P$ improves the probability of approval remarkably. Since, employment rate reflects the status of the local labor market, local authorities with active business have higher tax revenue. The result confirms the hypothesis that local authorities with ample taxation are more likely to permit new residential construction to accommodate more residents.

The municipal deficit $D E F$ has a significant effect in delaying the planning process. The probability of approval in the local authorities with a deficit is lower than those local authorities with fiscal surplus. This is because local authorities with deficits are unable to 
Table 3: Maximum likelihood estimates of Planning Hazard Model

\begin{tabular}{|c|c|c|c|c|}
\hline & \multicolumn{3}{|c|}{ Plan Variables } & Model 4 \\
\hline UN & $\begin{array}{l}-0.0011^{*} \\
(0.0006)\end{array}$ & $\begin{array}{l}-0.0010^{*} \\
(0.0006)\end{array}$ & $\begin{array}{l}-0.0011^{*} \\
(0.0006)\end{array}$ & $\begin{array}{c}-0.0022^{* *} \\
(0.0010)\end{array}$ \\
\hline$U N^{2}$ & $\begin{array}{l}7.22 \mathrm{E}-07^{*} \\
(4.22 \mathrm{E}-07)\end{array}$ & $\begin{array}{l}5.98 \mathrm{E}-07^{*} \\
(4.28 \mathrm{E}-07)\end{array}$ & $\begin{array}{l}6.04 \mathrm{E}-07^{*} \\
(4.29 \mathrm{E}-07)\end{array}$ & $\begin{array}{l}1.79 \mathrm{E}-06^{*} \\
(1.12 \mathrm{E}-06)\end{array}$ \\
\hline MORA & $\begin{array}{c}0.0971 \\
(0.1782)\end{array}$ & $\begin{array}{c}0.1307 \\
(0.1791)\end{array}$ & & \\
\hline$\angle O A D$ & $\begin{array}{c}-0.0140 * * * \\
(0.0017)\end{array}$ & $\begin{array}{c}-0.0129 * * * \\
(0.0018)\end{array}$ & $\begin{array}{c}-0.0127^{* * *} \\
(0.0017)\end{array}$ & $\begin{array}{c}-0.0100^{* * * *} \\
(0.0022)\end{array}$ \\
\hline$\sigma_{D A Y}$ & & & & $\begin{array}{l}-0.0003^{*} \\
(0.0002)\end{array}$ \\
\hline \multicolumn{5}{|c|}{ Municipal Variables } \\
\hline$D E F$ & $\begin{array}{c}-0.0002 * * \\
(0.0001)\end{array}$ & $\begin{array}{c}-0.0007^{* * *} \\
(0.0002)\end{array}$ & $\begin{array}{c}-0.0007^{* * *} \\
(0.0002)\end{array}$ & $\begin{array}{c}-0.0009^{* * *} \\
(0.0002)\end{array}$ \\
\hline$A C U D E F$ & & $\begin{array}{c}0.0006^{* * *} \\
(0.0002)\end{array}$ & $\begin{array}{c}0.0006^{* * *} \\
(0.0002)\end{array}$ & $\begin{array}{c}0.0008^{* * *} \\
(0.0003)\end{array}$ \\
\hline Dep & $\begin{array}{c}-7.8835^{* * * *} \\
(2.1598)\end{array}$ & $\begin{array}{c}-6.6901^{* * *} \\
(2.1793)\end{array}$ & $\begin{array}{c}-6.6283^{* * *} \\
(2.1652)\end{array}$ & $\begin{array}{c}-8.7454^{* * * *} \\
(2.5920)\end{array}$ \\
\hline$\triangle E M P$ & $\begin{array}{c}1.7708^{* * *} \\
(0.5517)\end{array}$ & $\begin{array}{c}1.8085^{* * *} \\
(0.5511)\end{array}$ & $\begin{array}{c}1.8602^{* * *} \\
(0.5383)\end{array}$ & $\begin{array}{c}1.0627^{* * *} \\
(0.7801)\end{array}$ \\
\hline$E D U$ & $\begin{array}{l}-0.0030 \\
(0.0085)\end{array}$ & $\begin{array}{l}-0.0022 \\
(0.0085)\end{array}$ & & \\
\hline$A R A B$ & $\begin{array}{c}0.1670 * * * \\
(0.0513)\end{array}$ & $\begin{array}{c}0.2141^{* * *} \\
(0.0547)\end{array}$ & $\begin{array}{c}0.2104^{* * *} \\
(0.0540)\end{array}$ & $\begin{array}{c}0.2039^{* * *} \\
(0.0603)\end{array}$ \\
\hline$I N C$ & $\begin{array}{l}0.0001 * \\
(0.0001)\end{array}$ & $\begin{array}{l}0.0001^{*} \\
(0.0001)\end{array}$ & $\begin{array}{l}0.0000^{*} \\
(0.0000)\end{array}$ & $\begin{array}{l}0.0001^{*} \\
(0.0000)\end{array}$ \\
\hline$\Delta P$ & $\begin{array}{c}-0.0002^{* * *} \\
(0.0000)\end{array}$ & $\begin{array}{c}-0.0002^{* * *} \\
(0.0000)\end{array}$ & $\begin{array}{c}-0.0001^{* * *} \\
(0.0000)\end{array}$ & $\begin{array}{c}-0.0001^{* * *} \\
(0.0000)\end{array}$ \\
\hline$\triangle P O P$ & $\begin{array}{c}-0.0530 * * * \\
(0.0106)\end{array}$ & $\begin{array}{c}-0.0491^{* * *} \\
(0.0107)\end{array}$ & $\begin{array}{c}-0.0499^{* * *} \\
(0.0106)\end{array}$ & $\begin{array}{c}-0.0442^{* * *} \\
(0.0110)\end{array}$ \\
\hline$\triangle I N C$ & $\begin{array}{c}-0.0007 * * * \\
(0.0002)\end{array}$ & $\begin{array}{c}-0.0007^{* * *} \\
(0.0002)\end{array}$ & $\begin{array}{c}-0.0006^{* * * *} \\
(0.0002)\end{array}$ & $\begin{array}{c}-0.0005^{* * * *} \\
(0.0002)\end{array}$ \\
\hline Likelihood & -1663.2498 & -1659.799 & -1660.1251 & -1460.1811 \\
\hline Observations & 1,364 & 1,364 & 1,364 & 1,277 \\
\hline
\end{tabular}

Notes: Duration variable is the number of days from the date when the plan was submitted until the date the plan was accepted. Cox proportional hazard equations, standard errors are reported in parentheses.

* Significance level at 10\%.** Significance level at $5 \%$.*** Significance level at $1 \%$.
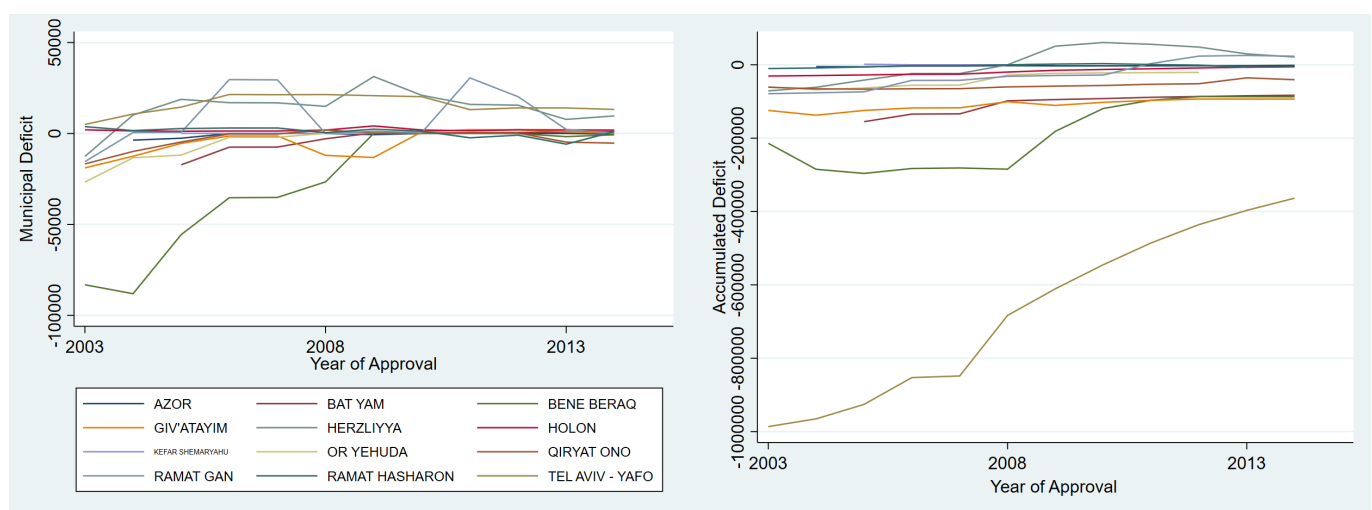

Figure 10. Deficit and Accumulated Deficit 
support population growth through increasing housing supply. This finding is consistent with [22]. They find municipalities with larger deficits tend to delay planning approval. As the municipal deficit grows (negative number) by one million NIS, planning time increases by between 0.2 and 0.5 days. An interesting result is that the accumulated deficit ACU DEF increases the probability of plan approval. Accumulated deficit reflects a municipal's long term fiscal status. As shown in Figure 10 the accumulated deficits are relative stable compare to the yearly deficits which fluctuate frequently. One possible explanation is that weak local authorities with long term fiscal distress tend to avoid obstructing the central government's planning process.

\section{Conclusion}

The urban growth literature has documented the patterns of urban land use under private land ownership and static equilibria. However, not much attention has been paid to the influence of population growth and public ownership on these patterns. The main focus of this chapter is to analyze the effect of local public finance on spatial land use through economic models and empirical evidence from Israel. Our theoretic models extends the Alonso-Mill-Muth model by incorporating local public finance. The first finding is that steady population growth provides a channel for land capitalization facilitated by the transacting land property rights over the long term. This implies a possible conflict of interest if the ownership of land leasing revenue and the ad valorem property tax are not consistent.

The empirical section examines one of the implications derived from the models in that there exists a possible inconsistency between central and local governments due to the land ownership centralization. Land ownership centralization causes local tax revenue inequality among the Israeli municipalities, and the statistical evidence shows that cities with a higher share of business area can generate more tax without assistance from the central government and are therefore more fiscal independent. The fiscal status has significant effect on the planning time for residential constructions. Municipalities with higher local tax revenue have shorter planning time(higher probability of acceptance) conditional on the plan's size and other features.

There is still much work to be done to understand more thoroughly the mechanism of local public finance under the framework of public land ownership. Future work may have several extensions, i) housing consumption is assumed to be fixed while this assumption simplifies the mathematics enormously and it also predetermines the equilibrium spatial development pattern. ii) in the two preceding sections, it was assumed that the level of benefits from local public goods does not vary over space in a city. In practice, however, the benefits from most local public goods do vary over space. This is because most local public goods are supplied from public facilities with fixed locations and finite spatial boundaries. iii) In the case of neighborhood good, its benefits are assumed to be uniform within a city (neighborhood), and no spillover effect is assumed to exist among cities (neighborhoods). In fact, residents of a neighborhood can free ride public service of an adjacent neighborhood. These extensions and relaxations may not lead to a competitive equilibrium such that the decentralization mechanism may not lead to an efficient outcome.

In conclusion, results from both the economic model and empirical findings have significant policy implications. First, in order to mitigate the conflicts, a transparent mechanism to distribute the land leasing revenue between the central government and the local authorities needs to be initiated to encourage the local authorities to approve construction on land zoned for housing. In the long term, such a mechanism needs to balance the central government's long term overall target and local authority's short term fiscal budget. Second, the natural rent produced by agglomeration indicates that the competitive equilibrium is hard to achieve though differential property taxation among cities based on different economic development levels. Agglomeration induces inequality in public service provision, which weakens competition and causes local authorities to become less effective in local public policies. Besides increasing housing supply, central 
government needs to balance the development of both strong and weak municipalities. Third, with respect to municipality-driven delays to the planning process, policies would need to avoid possible conflict of interests between local and central government. If relevant ministries regard the plan as high priority then special support would be provided to the relevant municipality, much like the "comprehensive agreements" 8 programme offered to municipalities to approve more construction.

Funding: This research received no external funding.

Acknowledgments: The authors would like to thank Prof. Daniel Felsenstein, Prof. Michael Beenstock for for helpful comments.

Conflicts of Interest: The authors declare no conflict of interest.

1. Capozza, D.R.; Helsley, R.W. The fundamentals of land prices and urban growth. Journal of Urban Economics 1989, 26, 295-306. doi:10.1016/0094-1190(89)90003-x.

2. Genesove, D. The Israeli Housing Market: Structure, Boom and Policy Response. Working Paper 2018.

3. Eckstein, Z.; Tolkowsky, E.; Eizenberg, A.B.L.; Sherman, Y. Do Local Authorities Face a Negative Incentive to Increase the Population under their Jurisdiction? Gazit Globe Real Estate Institute policy paper 2014.

4. Pines, D.; Sadka, E. Zoning, first-best, second-best, and third-best criteria for allocating land for roads. Journal of Urban Economics 1985, 17, 167-183. doi:10.1016/0094-1190(85)90044-0.

5. Glaeser, E.L.; Gyourko, J. Urban Decline and Durable Housing. Journal of Political Economy 2005, 113, 345-375. doi:10.1086/427465.

6. Rubin, Z.; Felsenstein, D. Supply side constraints in the Israeli housing market-The impact of state owned land. Land Use Policy 2017, 65, 266-276. doi:10.1016/j.landusepol.2017.04.002.

7. Werczberger, E.; Borukhov, E. The Israel Land Authority: relic or necessity? Land Use Policy 1999, 16, 129-138. doi:10.1016/s0264-8377(99)00014-9.

8. Borukhov, E. Land policy in Israel. Habitat International 1979, 4, 505-515. doi:10.1016/01973975(79)90061-4.

9. Eckstein, Z.; Perlman, M. Competition and privatization of land in Israel. The Economics Quarterly 1997, 44, 574-606.

10. Beenstock, M.; Felsenstein, D.; Xieer, D. Long-term housing affordability in spatial general equilibrium. Housing Studies 2020, pp. 1-34. doi:10.1080/02673037.2020.1736520.

11. Portnov, B.A.; McCluskey, W.J.; Deddis, W.G. Property taxation in Israel: a non ad valorem approach. Land Use Policy 2001, 18, 351-364. doi:10.1016/s0264-8377(01)00029-1.

12. Horne, R.; Felsenstein, D. Is property assessment really essential for taxation? Evaluating the performance of an 'Alternative Assessment' method. Land Use Policy 2010, 27, 1181-1189. doi: 10.1016/j.landusepol.2010.03.008.

13. Ben-Bassat, A.; Dahan, M.; Klor, E.F. Is centralization a solution to the soft budget constraint problem? European Journal of Political Economy 2016, 45, 57-75. doi: 10.1016/j.ejpoleco.2016.09.005.

14. Baskaran, T.; Brender, A.; Blesse, S.; Reingewertz, Y. Revenue decentralization, central oversight and the political budget cycle: Evidence from Israel. European Journal of Political Economy 2016, 42,1-16. doi:10.1016/j.ejpoleco.2015.12.001.

15. Ben-Bassat, A.; Dahan, M. The political economics of the municipalities. Jerusalem, Israel: The Israel Democracy Institute 2009.

16. Razin, E. Local government reform in Israel: Between centralization and decentralization between traditionalism and modernity. Jerusalem: Floersheimer Institute for Policy Studies (Hebrew) 2003.

17. Alonso, W.; others. Location and land use. toward a general theory of land rent. Location and land use. Toward a general theory of land rent. 1964.

18. Mills, E.S. An aggregative model of resource allocation in a metropolitan area. The American Economic Review 1967, 57, 197-210.

8 "Comprehensive agreements" are a municipality-central government fix to rapidly develop state owned land for housing. Under these agreements municipalities permit rapid housing unit development in exchange for central government financed pre-development costs and infrastructure. 
19. Muth, R.F. CITIES AND HOUSING; THE SPATIAL PATTERN OF URBAN RESIDENTIAL LAND USE. 1969.

20. Fujita, M. Spatial patterns of residential development. Journal of Urban Economics 1982, 12, $22-52$. doi:10.1016/0094-1190(82)90003-1.

21. Capozza, D.R.; Helsley, R.W. The stochastic city. Journal of Urban Economics 1990, 28, 187-203. doi:10.1016/0094-1190(90)90050-w.

22. Rubin, Z.; Felsenstein, D. Is planning delay really a constraint in the provision of housing? Some evidence from Israel. Papers in Regional Science 2019, 98, 2179-2200. doi:10.1111/pirs.12440. 
